\title{
Teaching in martial arts: The analysis and identification of teaching approaches in youth martial arts practice
}

\begin{tabular}{|c|c|}
\hline & Iors' Contribution: \\
\hline A & Study Design \\
\hline B & Data Collection \\
\hline $\mathrm{C}$ & Statistical Analysis \\
\hline D & Manuscript Preparation \\
\hline $\mathbf{E}$ & Funds Collection \\
\hline
\end{tabular}

\author{
Jikkemien Vertonghen ${ }^{1 \mathrm{ABCDB}}$, Marc Theeboom ${ }^{1 \mathrm{AD}}$, Marc Cloes $^{2,3 \mathrm{BD}}$ \\ ${ }^{1}$ Department of Sports Policy and Management, Vrije Universiteit Brussel, Belgium \\ ${ }^{2}$ Department of Sport Pedagogy, Université de Liège, Belgium \\ ${ }^{3}$ Department of Sport and Rehabilitation Sciences, University of Liege, Belgium
}

Source of support: Departmental sources

Received: 20 October 2011; Accepted: 23 May 2012; Published online: 12 October 2012

\begin{abstract}
Background It is believed that martial arts can produce educational opportunities for youth. Therefore, some critical success and Study Aim: factors have to be taken into account. One of these factors is considered as the type of guidance. However in martial arts, there is a lack of research examining the role of the martial arts teacher. Therefore, a study was set up to analyse different teaching approaches used in martial arts and to develop a framework aiming to identify these teaching methods.
\end{abstract}

Material/Methods: A multiple instruments research design was set up, in which 20 teachers in aikido $(\mathrm{n}=5)$, karate $(\mathrm{n}=10)$ or kick-/Thai boxing $(n=5)$ were involved. All of them were observed during a training session (i.e., informal interactive observation). Moreover, they were interviewed before and afterwards (i.e., pre-interactive and post-interactive interviews). The pre-interactive interview guide included questions regarding (a) the goal of teaching, (b) the didactical approaches, (c) the traditional aspects of martial arts, and (d) the problems encountered during training. During the post-interactive interview all subjects were asked to point out specific aspects of their teaching approach and to respond to an instrument specifically developed for this study, which consists of seven dimensions to identify different teaching approach (i.e., TAMA, Teaching Approach in Martial arts framework).

Results: Based on the total scores of TAMA, martial arts teachers were classified into three groups. Those with the lowest scores were classified as representatives of a traditional teaching approach, with medium scores as teachers using an educational sporting approach and with the highest scores as those using an efficiency approach. In short, teachers using a traditional teaching method emphasised traditional aspects and pedagogically oriented aims. Martial arts teachers situated in the educational sporting group were still focused on the traditional aspects, but considered martial arts rather more as a sport. And finally, the focus of teachers using an efficiency approach was on competition and the development of performing skills.

Conclusions: Differences are clearly identified in the teaching approach used by teachers of different martial arts (i.e., aikido teachers use a traditional approach while kick-/Thai boxing teachers show an efficiency approach), as well as within one martial art (i.e., karate teachers use all three approaches). The development of TAMA was the first onset to identify different teaching approaches in martial arts. In order to generalise the results of the present study further research is recommended

Key words: $\quad$ youth $\bullet$ martial arts $\bullet$ martial arts teacher $\bullet$ teaching $\bullet$ teaching approach

Author's address: Jikkemien Vertonghen, Vrije Universiteit Brussel, Pleinlaan 2, B-1050 Brussels, Belgium; e-mail: jikkemien.vertonghen@vub.ac.be

\section{BaCKGRound}

To date, practising a martial art (e.g., karate, judo, kickboxing) is a popular sports activity in many countries all over the world (e.g., Australia: [1]; Canada: [2]; Europe: [3]). Some studies even revealed that martial arts are in the top ten of most practised sports in a club-related context among children and adolescents $[1,3,4,5]$. A 
15. Wright PM, White K, Gaebler-Spira D: Exploring the relevance of the personal and social responsibility model in adapted physical activity: A collective case study. J Teach Phys Educ, 2004; 23(1): $71-87$

16. Wall RB: Teaching Tai Chi with mindfulness-based stress reduction to middle school children in the inner citv: a review of the literature and approaches. Med Sport Sci, 2008; 52: 166-72

17. Twemlow SW, Biggs BK, Nelson TD et al: Effects of participation in a martial arts-based antibullying program in elementary schools. Psychol Schools, 2008; 45(10): 947-59

18. Gonzalez CMT, Cano AI, Alonso AP: Culture of peace and non-violence. Self-defense as a pedagogic proposal. Rev Int Med Cienc Act Fis Dep, 2008; 8(31): 199-211

19. Kitamura T, Ando H, Kawanishi M, Hamada HY: What will you teach through martial arts? In: Söderström T, Fahlén J, Wickman K (eds.), People in motion. Bridging the local and global. Book of abstracts, $8^{\text {th }}$ European Association for Sociology of Sport; 2011; Sweden: Umea University; p. 187

20. Coalter F: A wider social role for sport: Who's keeping the score? London: Routledge; 2007

21. Mahoney J, Stattin H: Leisure activities and adolescent antisocial behavior: The role of structure and social context. J Adolesc, 2000; 23: 113-27

22. Petitpas A, Cornelius A, Van Raalte J, Jones T: A framework for planning youth sport programs that foster psychosocial development. The Sport Psychologist, 2005; 19: 63-80

23. Shields DLL, Bredemeier BJL: Character development and physical activity. Champaign, IL: Human Kinetics, 1995

24. Zarrett N, Lerner R, Carrano J et al: Variations in adolescent engagement in sports and its influence on positive youth development. In: Holt NL (ed.), Positive Youth Development Through Sport. London: Routledge, 2008; 9-23

25. Theeboom $M$, Verheyden $E$ : Vechtsporten met een + . Extra kansen voor kwetsbare jongeren. |Martial arts with a + . Additional opportunities for socially deprived youth]. Brussel: Vubpress, 2011

26. Vertonghen J: The analysis of contextual factors in youth martial arts practice. Brussel: Vubpress, 2011
27. Vertonghen J, Theeboom M: The social-psychological outcomes of martial arts practise among youth: A review. J Sports Sci Med, 2010; 9(4): 528-37

28. Harasymowic J: Competences of combat sports and martial arts educators in light of the holistic fair self-defence model of training. Archives of Budo 2007; 3: 7-14

29. Kozub F, Kozub M: Teaching combative sports through tactics. Journal of Physical Education, Recreation and Dance, 2004; 72(8): 16-21

30. Theeboom M, De Knop P, Wylleman P: Traditional Asian martial arts and the West. Journal of Comparative Physical Education and Sport, 1995; 17: $57-69$

31. Theeboom M, Vertonghen J: 'It is like a finger pointing away to the moon'. Teaching martial arts to children. In: Cynarski W, Obodynski K, Porro N (eds.), Sports, Bodies, Identities and Organizations: Conceptions and Problems. Rzeszów: European Association for Sociology of Sport, 2011; 68-79

32. Capel S: Learning to Teach Physical Education in the Secondary School: A Companion to School Experience. London, Routledge, 2004

33. Graham G: Teaching children physical education: becoming a master teacher. Champaign, IL: Human Kinetics, 2008

34. Rink J: Teaching physical education for learning ( $3^{\text {nd }}$ ed.). Boston: McGraw-Hill; 1998

35. Figueroa P: Equality, multiculturalism, antiracism and physical education in the National Curriculum. In: Evans I (ed.), Equality, Education and Physical Education. London: Falmer Press, 1993; 90-104

36. Metzler M: Instructional models for physical education ( $2^{\text {nd }}$ ed.). Scottsdale, AR: Holcomb Hathaway, 2004

37. Murray JF: An analysis of two methods of teaching falling in judo. Int J Sport Psychol, 1981; 12: 275-81

38. Förster A: The nature of martial arts and their change in the West. In: Kleinman S, (ed.), Mind and body. East meets West. Champaign, IL: Human Kinetics, 1986; 83-88

39. Martens R: Successful Coaching ( $3^{\text {rd }}$ ed.) Champaign, IL: Human Kinetics, 2004

40. Cox JC: Traditional Asian martial arts training: a review. Quest, 1993; 45: 366-88
41. Jones GW, MacKay KS, Peters DM: Participation motivation in martial artists in the West Midlands region of England. J Sports Sci Med, 2006; 5: 28-34

42. Donohue J, Taylor K: The classification of the fighting arts. Journal of Asian Martial Arts, 1994; 3(4): 10-37

43. Nosanchuk TA, MacNeil ML: Examination of the effects of traditional and modern martial arts training on aggressiveness. Aggressive Behavior, 1989; 15: 153-59

44. Trulson ME: Martial arts training. A novel cure for juvenile delinquency. Human Relations, 1986; 39: $1131-40$

45. Back A, Kim D: The futtre course of the Eastern martial arts. Quest, 1984; 36: 7-14

46. Theeboom M, Van Stiphout E: De oosterse vechtsporten: kan u nog volgen? 2. Kenmerken en plaats binnen de lichameliike opvoeding. |The Eastern martial arts: Can you still follow? 2. Characteristics and position in the physical education $]$. Tijdschrift voor Lichamelijke Opvoeding, 1993; 4: 11-17

47. Allemann B: Aikido. The martial arts series. London: New Holland Publishers, 2004

48. Brudnak M, Dundero D, Van Hecke F: Are the 'hard' martial arts, such as the Korean martial art, TaeKwon-Do, of benefit to senior citizens? Medical Hypotheses, 2002; 59(4): 485-91

49. Coolican H: Research methods and statistics in psychology. London: Hodder Education, 2009

50. Villamon M, Brown D, Espartero J, Gutiérrez C: Reflexive modernization and the disembedding of judo from 1946 to the 2000 Sydney Olympics. Int Rev Sociol Sport, 2004; 39(2): 139-56

51. Groenewold M: Karate the Japanese way. Canada: Trafford Publishing, 2002

52. Kohn T: The Aikido Body: Expressions of Group Identities and Self Discovery in Martial Arts Training. In: Dyck N, Archetti EP (eds.), Sport, dance and embodied identities. Oxford: Berg Press, 2003; 139-56

53. Lyle J: Sports coaching concepts: a framework for coaches' behaviour. London: Routledge, 2002 
for years, but that they want to achieve proficiency and rank advancement rapidly.

In this paper the term 'teaching' has always been used. With regard to the traditional approach, the term is well-chosen, because in this context teaching seems to be about providing pupils a martial arts education. It should be noted, however, that the naming is not applicable for all aspects described in this article. For example, the items linked to the efficiency approach would come closer to what is generally thought of as coaching (i.e., improving sports performance and preparing and guiding pupils to perform in a competitive context [53]).

Finally, the development of TAMA was a first onset to identify teaching approaches of martial arts teachers by using a quantitative methodology. It is important to state that TAMA is a "research tool under construction" and that the findings of the present study cannot be generalised because the characteristics described in TAMA are based on martial arts clubs involved in this study. Furthermore, in the present study also a qualitative research design was set up to discuss each item of TAMA more in-depth with the martial arts teachers. However, in order to expand the use of TAMA in further research, it is suggested to test and validate TAMA in (a) other countries and (b) other martial arts. After that, the framework could be used to evaluate teaching methods and the effects these methods have on students' performance, behaviour, attitudes, etc.

\section{Conclusions}

Martial arts have often been used as an educational tool to work with youth. However in order to provide educational opportunities it is important to take several critical success factors into account, such as the type of guidance. Because of the lack of insight into this factor, the present study was a first attempt to obtain a better understanding of the type of guidance within martial arts. It was aimed to analyse different teaching approaches used by martial arts teachers and to develop a framework in order to identify these teaching methods. Findings revealed differences in the teaching approach used by teachers of different martial arts (i.e., aikido teachers use a traditional approach and kick-l Thai boxing teachers an efficiency approach), as well as within one martial art (i.e., karate teachers use all three approaches). However, as TAMA is a "tool under construction", more research is recommended to examine (a) the type of guidance in martial arts in general and (b) different teaching approaches used by martial arts teachers in particular.

The present study provided a better understanding of teaching approaches used in martial arts. However, as indicated by Theeboom et al. [30], it can be expected that the different teaching approaches might have a distinct effect on participants' experiences. Therefore, it might be relevant in further research to examine how these different approaches would be perceived by young participants and to what extent differences in teaching approaches might result in a variation in pupils' experiences. In this context, it is also relevant to take into account that still other critical success factors, different from the teaching approach, might influence experiences of young participants, such as the type of sport, characteristics of the participants, social context, organisational setting (formal or informal), nature of parental involvement and participants' individual experiences [20-24]. Consequently, more research is necessary that looks more closely at these factors and their interrelationships. It would be relevant therefore to develop a model to provide more insight into the relationship between these factors and determine the extent to which each factor affects the experiences of young martial artists.

\section{REFERENCES:}

1. Australian Bureau of Statistics: Children's participation in cultural and leisure activities. 2009 [cited 2010 Jan 21]. Available from: URL: http://www.abs.gov.au/AUSSTATS/abs@.nsf/ DetailsPage/4901.0Apr\%202009? OpenDocument

2. Ifedi F: Sport Participation in Canada, 2005 (Catalogue no. 81-595-MIE2008060). Ottawa: Culture, Tourism and the Centre for Education Statistics; 2008

3. van Bottenburg M, Rijnen B, van Sterkenburg J: Sports participation in the European Union. Trends and differences. 's Hertogenbosch - Nieuwegein: W.J.H. Mulier Institute - Arko Sports Media; 2005

4. Warren C: Kids' sports. Canadian Social Trends, 2008; 11: 54-61

5. Wolt K, Bosveld W, Slot J: Sportmonitor 2006: Inzicht in het sportgedrag van Amsterdammers [Sport monitor 2006: Insight in sport behavior of the citizen of Amsterdam]. Amsterdam: Dienst Maatschappelijke Ontwikkeling, 2007
6. Scheerder J, Vos S: Sportclubs in Beeld. Basisrapportering over het Vlaamse Sportclub Panel 2009 [Sports clubs in the pictures. Report of the Flemish Sports Panel 2009]. Heverlee: Katholieke Universiteit Leuven; 2010

7. Abrahams C: Inspire guidance-based martial arts program: A self-esteem intervention for at-risk elprogram: A self-esteem intervention for at-risk el-
ementary and middle school students. Compelling Counseling Interventions: Vistas; 2004 [cited 2009 Jan 23]. Available from: URL: http:// counselingoutfitters.com/vistas/vistas04/20.pdf

8. Bosch A: Handboek FUNdamentals. Creëren van een sociaalpedagogisch vechtsportklimaat [Handbook Fundamentals. Create a social-pedagogical martial arts climate]. Arnhem: KNKF, Tijd voor Vechtsport, 2008

9. Hébert J: Arts martiaux, sports de combat et interventions psychosociales [Martial arts, combat sports and psychosocial interventions]. Quebec: Presses de l'Université du Québec; 2011
10. Theeboom M, De Knop P, Wylleman P: Martial arts and socially vulnerable youth. An analyse of Flemish initiatives. Sport Education and Society, 2008; 13(3): 301-18

11. Brown D, Johnson A: The social practice of self-defense martial arts: Applications for physical eduction. Quest, 2000; 52: 246-59

12. Winkle J, Ozmun J: Martial arts: An exciting addition to the physical education curriculum. The Journal of Physical Education, Recreation and Dance, 2003; 74(4): 29-35

13. Theeboom M, De Knop P: Asian martial arts and approaches of instruction in physical education. European Journal of Physical Education, 1999; 4 : 146-61

14. Wright PM, Burton S: Implementation and outcomes of a responsibility-based physical activity program integrated into an intact high school physical education class. J Teach Phys Educ, 2008; $27(2): 138-54$ 
traditional group, whereas nearly all kick-/Thai boxing teachers were classified in the efficiency group (with the exception of one who was found in the educational sporting group). This means that different teaching approaches can be observed in different martial arts. Furthermore, the participating karate teachers were found in all three groups. Aikido and kick-/Thai boxing are more homogeneous martial arts as compared to karate, because many different styles exist within karate (e.g., non-contact styles such as shotokan karate and full-contact styles, such as kyokushinkai karate). This can explain why aikido and kick-/Thai boxing teachers are each found in one groups (i.e., aikido in the traditional and kick-/Thai boxing in the efficiency group), while karate teachers are found within all three groups. With this reasoning, it would be expected that teachers within one specific karate style (e.g., shotokan karate) would use the same teaching approach. Results of the present study, however, indicated something different, namely kyokushinkai teachers were situated in the educational sporting and efficiency group and teachers teaching shotokan karate were classified in all three groups. This finding indicates that within one martial art style different teaching approaches can be found which is consistent with Jones et al. [41]. These authors stated that within one martial art many differences could occur, among other reasons, because of differences in the teaching approach of martial arts teachers.

Results of the present study show that teachers of the three teaching approaches strive towards different goals. Teachers who are using a traditional approach in teaching martial arts to youngsters have indicated that the traditional aspects are important as they are regarded as an added value. Furthermore, pedagogically oriented goals are one of their main objectives. Teachers using an educational sporting approach also considered the traditional and pedagogical elements of teaching martial arts as important, but rather regard martial arts as a sport. They emphasised the physical and sporting aspects of practising a martial art. This can be due to the fact that competition was considered as more important in the educational sporting approach than in the traditional approach. Finally, teachers using an efficiency approach were primarily focused on taking part in competition and offering a sporting activity. They also stressed the importance of the technical and tactical aspects of martial arts in order to perform techniques as effective as possible.

This variety of goals is similar to an earlier described martial arts classification system of Theeboom et al. [30] (i.e., traditional, sporting, efficiency). According to these authors, the occurrence of these three approaches is a result of the many changes that Asian martial arts (e.g., judo, taekwondo, karate and aikido) have undergone since they were introduced in the West. Several authors stated that several specific characteristics of Asian martial arts (cultural, historical, spiritual, artistic and embodied significance) are disregarded in the West $[30,38]$. In judo, for example, Villamon et al. [50] indicated that the Budo elements (e.g., mental and spiritual discipline, moral development, harmony between the physical and mental level) were removed and reembedded within a western competitive sporting context. However, findings of the present study revealed that the Budo elements are not completely disregarded in the West, but that some teachers have adopted them more than others. This might explain the differences that were found within karate.

Furthermore, next to the aim of the martial arts teachers, six other dimensions were discussed in this study to determine the teaching approach used by martial arts teachers. In some dimensions, teachers in the educational sporting group showed similarities with those of the traditional group (i.e., duration of the opening and closing ritual, teaching techniques globally or analytically and use of traditional or efficient techniques) and, in other dimensions, with those of the efficiency group (sparring and response to inappropriate behaviour). Although we previously classified all teachers into three groups, this finding might indicate that teachers can actually be situated on a spectrum line. This would show that every martial arts teacher has his own teaching approach, but that similarities can be found between the different approaches.

Another interesting finding was that some interviewees indicated that when teachers use a traditional or an educational sporting approach, it takes much longer to master different techniques or to achieve a higher belt than when the efficiency approach is used. In the literature, several authors also reported this. They stated that a true understanding of martial arts, such as aikido and karate, demands years of dedicated practice $[51,52]$. The dimensions in which the traditional and educational sporting groups showed similarities could be a possible explanation for this finding. For example, to teach a technique using an analytical teaching approach will take much more time than when a global teaching method is used. Also, teachers who use a traditional or educational sporting approach held on to traditional techniques and consider technical perfection as very important, while teachers of the efficiency group found this approach too time-consuming and focused primarily on effectively performing a technique. This is consistent with Back and Kim [45]. Although these authors mainly focused on the westernisation of traditional martial arts, they argued that in the West pupils tend not to be prepared to engage a martial art 
However, three teachers of the traditional group indicated that it is possible to develop some technique variations, but only once you have become an expert in your martial art (after many years of training).

All trainers classified in the efficiency group said they allow small changes to make a technique more efficient:

'In traditional martial arts, your feet must not be positioned like this, but rather like that. In kick-/Thai boxing you can put your foot like this, that's not a problem.' (Kick-/Thai boxing I)

\section{Teaching techniques by an analytical or a global method}

To teach martial arts techniques to youngsters several methods can be used (i.e., analytical versus global). Results revealed that the martial arts teachers who used a traditional or an educational sporting approach mainly taught techniques analytically, whereas teachers of the efficiency group used a more global method.

The interviews revealed that a majority of the traditional and educational sporting martial arts teachers $(n=12)$ analyse each new technique step by step, because otherwise it would be too difficult:

'I work very analytically. I split up a technique into different movements and then they have to practise one movement at least 10 times ... and then the next one.' (Karate 9)

It is interesting to note that most teachers of the traditional and educational sporting group said that sometimes they have to introduce some variety to make training more enjoyable. One teacher using a traditional approach also stated that he works with themes during a number of training sessions. Only when everyone has mastered the techniques, the teacher moves on to the next topic:

'Now we have been working for three months on "going out of the line of the attack". Last year, my theme was working with your hands in front of your body. We do not have a schedule, we just look whether or not they know the principle, and if so, we start on a new theme. Sometimes one theme can take a whole year.' (Karate 3 )

Contrary to the traditional and educational sporting teachers, the majority of those using an efficiency approach $(n=5)$ said they teach techniques mainly in their globalism, because it would otherwise he too boring for the youngsters. One teacher also indicated that it would take too long if each technique had to be analysed separately:

'Imagine that you come to me and you want to become a good fighter. With a traditional approach it would take more than
6 years. That is not the case in my club. We want to work as well and as efficiently as possible to make a good boxer of someone. '(Kick-/Thai boxing 5)

\section{Response to inappropriate behaviour during training}

Teachers were asked how they react if youngsters show inappropriate behaviour during training. Results revealed that traditional martial arts teachers use a more gentle method, which is more intrinsically and mentally oriented. They motivate youngsters verbally or make them reflect on their behaviour:

'If someone distupts the training session, I say: "Get back on your knees with your eyes closed as in the opening ritual. And once you think you're ready, you can come back and participate." So they just have to learn to think about their own behaviour.' (Karate 2)

Teachers with an educational sporting or efficiency teaching style used a somewhat harder approach in comparison with traditional teachers within this study. Punishments are more extrinsically and physically oriented (e.g., push-ups, sit-ups, running, etc.). Although educational sporting and efficiency teachers show some similarities, the second group even goes one step further. Two teachers who use an efficiency approach stated that if someone does not behave properly, he or she has to practise with someone who is stronger than him/ her. Also some efficiency teachers $(n=3)$ indicated that if someone breaks the rules on several occasions, he or she could be suspended.

However, two teachers with an efficiency teaching style used a more gentle approach similar to traditional teachers in this study. They feel that physical punishment is merely the easiest solution and they would consider it as a personal weakness. They believe that a mentally oriented approach is more effective, because it makes pupils think about their own behaviour.

\section{Discussion}

In the present study, an analysis was made of the characteristics of different teaching approaches used by martial arts teachers (i.e., aikido, karate and kick-/Thai boxing).

Based on a self-developed measurement tool, the 'Teaching Approach in Martial Arts' framework (TAMA), three different teaching approaches were identified amongst the participating martial arts teachers (i.e., the traditional, educational sporting and efficiency approach). In order to provide an answer to the research questions that were formulated in this study, it is interesting to note that all aikido teachers were found in the 
'We don't do greetings; we're in a boxing club.' (Kick-/Thai boxing 5)

\section{Ability groups}

In this study, martial arts teachers were asked whether or not they divide youngsters into ability groups.

Teachers who used a traditional approach rarely or never divided youngsters into ability groups. The results of the interviews showed that doing so, teachers want to emphasise the fact that youngsters have to help each other and learn from one another:

'I could divide participants into groups, because some youngsters are more advanced than others. In this way, they would also make more progress, but this is not what aikido is about.' (Aikido 5)

Most teachers $(n=4)$ using an educational sporting approach have grouped youngsters according to their level of experience, but only for one part of the training, and mostly for teaching techniques.

One teacher using an educational sporting approach indicated that he puts all the youngsters who are interested in competition into one group. This approach is comparable to that of the teachers who used an efficiency approach. All these teachers had a special competition group or divided their pupils according to the preparation for a contest. Teachers indicated that this is a better way to train more specifically. One teacher even indicated that he works with individual trainees.

\section{Sparring}

Teachers were asked what they understood by 'sparring'. All teachers used the same general description, namely 'working in pairs to practise techniques'. Nevertheless, it was clear that there were three noticeable differences in their interpretations, particularly between teachers using a traditional approach and those using an educational sporting or efficiency method:

a. Some traditional teachers stated that they do not talk about an opponent, but rather about a partner. Also, a majority of them $(n=5)$ indicated that, instead of two persons attacking simultaneously, more often only one person performs a technique, while the other one undergoes the technique. Additionally, they stated that the latter has to help the performer so that they can be united with each other. In this kind of task, youngsters do not compete with their partner; they only know whether they performed the technique correctly. Furthermore, it is worth mentioning that winning and losing also occur in such exercises, as illustrated by the following quote:
The will to win is stimulated, not individually, but in cohesion with their partner. In a sparring exercise they only deserve their points if they both perform equally well, so they have to help each other as much as possible.' (Aikido I)

b. Some teachers using a traditional teaching approach $(n=3)$ perceived sparring as being some kind of free fight, in which both individuals attack. However, they indicated that this kind of exercise is hardly part of their training.

c. Teachers of the educational sporting or efficiency group also considered sparring as a kind of free fight, but they said that it occurs more frequently during training sessions. One of the teachers stated that it is a simulation of a real fighting contest.

With regard to the interpretation of sparring, the difference between educational sporting and efficiency teachers is that the first ones emphasise the fact that the participants have to help each other and learn from each other during a sparring session, while the efficiency teachers view it more individually. Several teachers $(n=3)$ using an efficiency approach indicated that during sparring pupils have to try the techniques they have learned and look for the weaknesses of their opponent. Most teachers situated in the efficiency group $(n=5)$ stated that sparring does not mean trying to hurt one's partner, it means showing respect for one another:

'For me, sparring is trying out what you have learned. Trying to use your technical skills in a confrontation with an opponent. You should not only think about performing your techniques, but you should also think about what your opponent will do... Sparring isn't about knocking each other down or finding out who is the best.' (Kick-/Thai boxing 2)

\section{Use of traditional or efficient techniques}

Subjects were asked whether they would tolerate small adjustments in a technique in order to perform it more efficiently. Findings showed that a majority of teachers who use a traditional $(n=8)$ as well as those who use an educational sporting approach $(n=4)$ prefer to stick to the traditional techniques:

"If I would change some of the techniques, they would no longer be correct. And if you try to get a black belt later on, you'll have to perform your techniques in front of a jury. So I cannot change them, because otherwise the jury would say: "Where did they learn that?!".'(Karate 6)

One teacher (Karate 3) also stated that the focus of his training was not on being as efficient as possible, but rather on teaching pupils as much as possible. 
'We try to give youngsters a sense of self-esteem through club disciplines ... Even if they stop practising aikido, the benefits will last for the rest of their lives.' (Aikido I)

It is worth mentioning that one teacher emphasised the pedagogical importance by having a conversation during the first five minutes of each training session about a specific theme, such as respect, neatness, honesty and courage.

Furthermore, it is also noteworthy that some traditional martial arts teachers $(n=3)$ pointed to the importance of the traditional aspects of their martial arts practice. Some considered it very important to pass on the values of the founder of the specific martial art to their pupils.

Teachers using an educational sporting approach also attached great importance to pedagogical and educational goals, but in comparison with teachers using a traditional approach, they emphasised more the sporting and physical aspects of their martial arts practice. The traditional values of martial arts were still respected, but they were of lesser concern.

It is interesting to mention that some teachers who use an educational sporting teaching approach $(n=3)$ indicated that they adapt themselves to the goals of their pupils:

'I teach children, elite athletes, seniors, ... I am like a chameleon, I adapt myself to every situation ... In my club I make a distinction depending on the students' goals ... for those who want to participate in competitions, the competitive aspect is important. For those who don't, self-development is most important.' (Karate 5)

Finally, the majority of teachers using an efficiency approach $(n=5)$ said that providing a sports activity was their most important goal when teaching martial arts to youngsters. Results showed that their training sessions were primarily focused on participating in competition. Although most teachers using an efficiency approach indicated that taking part and doing their best was their main objective, some teachers $(n=3)$ have stated that winning in competition is also important.

Some teachers $(n=3)$ indicated that teaching techniques as well as the technical and tactical aspects of martial arts were very important:

'For me, it is very important that my youngsters have technical and tactical insight. They have to understand their own martial art.' (Kick-/Thai boxing 2)

Furthermore, it is interesting to note that several teachers $(n=4)$ using an efficiency approach stated that their training sessions are physically very intense so that their students go home with a sense of satisfaction.

Also one teacher indicated that he wants to keep youngsters off the streets by offering them a sports activity that interests them. In this way they are safeguarded from perilous situations and have something to talk about:

'I prefer youngsters to practise sports and be engaged in positive activities rather than hang about, because that can sometimes mean getting into trouble. I prefer them to have a good training session of an hour and a half. Afterwards they are tired and only think of having a shower, something to eat and going to bed ...' (Kick-/Thai boxing 4)

Finally, results of the interviews revealed that all teachers emphasised the importance that everyone can get along with other club members and show respect for each other.

\section{Opening and closing ritual}

Whatever their approach, teachers indicated that an opening and closing ritual at the beginning and end of training is meant to teach young people respect. The results of this study, however, showed differences in the ritual depending on the teaching method being used. Findings revealed that teachers using an efficiency approach paid less attention to the greeting ritual compared to those who use a traditional or an educational sporting approach. The two latter groups considered it as an important part of training. Some of them $(n=5)$ also included a moment of meditation in the ritual, during which they sat on their knees with their eyes closed for about one minute and tried to set aside everything else:

'During training, there are two moments when I expect youngsters to be absolutely quiet, and that's at the beginning and the end of the session. It is a way of showing respect for everything that has to do with aikido.' (Aikido 3)

Some teachers $(n=4)$ who made use of an efficiency approach have also indicated that an opening and closing ritual is important for the youngsters. It makes the training more structured, but it is mostly just a line-up and it does not take long:

'I don't intend to sit down and give a half hour explanation each time, but it is good to indicate the beginning and the end of a training session. Many young people are no longer interested in such things. They say: "The time I spend greeting I could have been sweating".' (Kick-/Thai boxing 4)

Some teachers $(n=2)$ who used an efficiency approach also indicated that an opening and closing ritual is not part of their training sessions: 


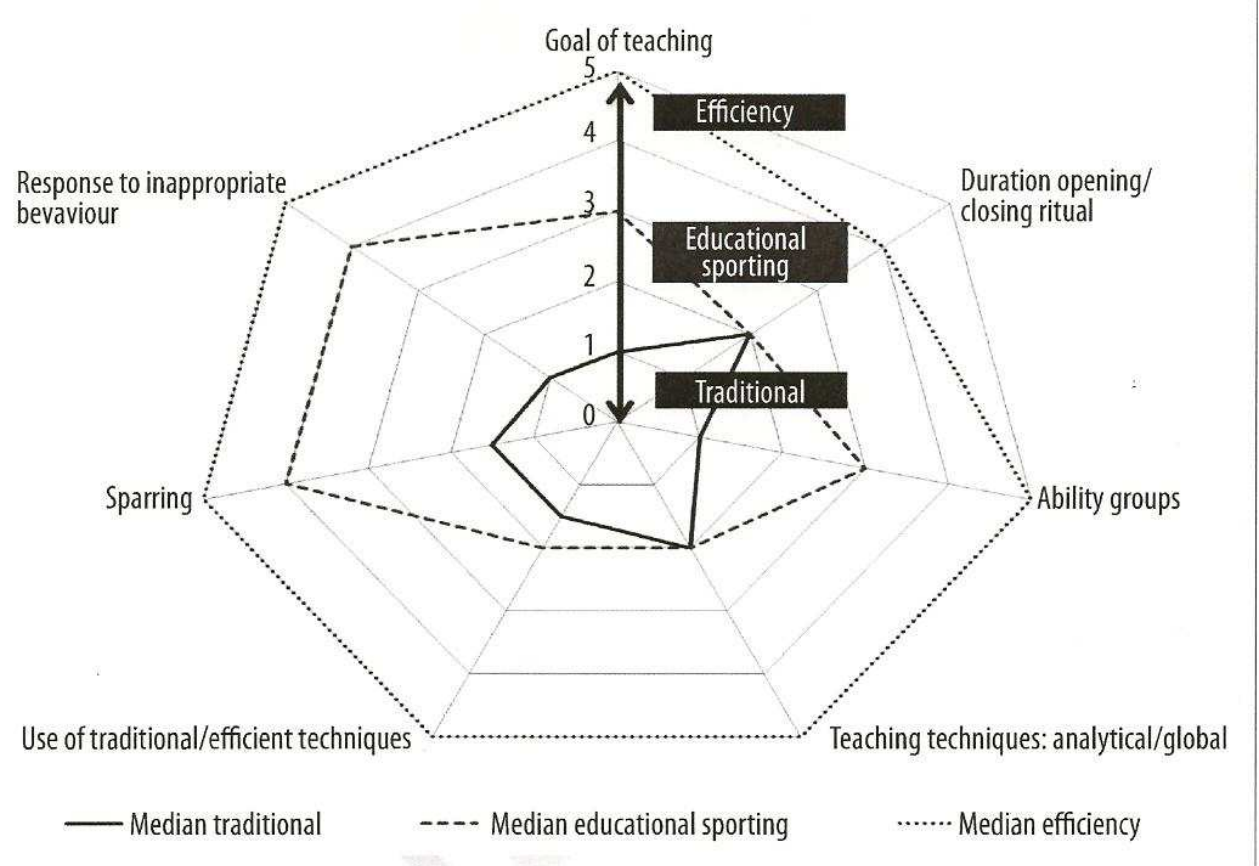

Figure 1. The median score of three groups of martial arts teachers for all dimensions of TAMA.

found in the traditional group and the majority of the kick-/Thai boxing teachers in the efficiency group. One interviewee, who teaches kick-/Thai boxing, was classified in the educational sporting group which primarily consisted of karate teachers. However, the latter were found in all three groups.

Furthermore, for each dimension of TAMA a median score was calculated for the different groups (Figure 1).

Obviously, findings have shown that martial arts teachers classified in the traditional group had the lowest scores on each item $(M d n \leq 2)$. The highest scores were found among the teachers of the efficiency group. Only for one dimension (i.e., duration of opening and closing ritual) those teachers had a median score lower than five $(M d n=4)$.

However, it is noteworthy that teachers using an educational sporting approach showed similarities for some dimensions with teachers using a traditional approach and for other dimensions with teachers using an efficiency approach. Hence, teachers of the educational sporting and traditional group had almost the same median scores for the following dimensions: (a) duration of the opening and closing ritual, (b) teaching techniques globally or analytically and (c) use of traditional or efficient techniques. While teachers of the educational sporting group had almost the same median score as those of the efficiency group for: (a) sparring and (b) how the teacher responds to inappropriate behaviour.
For the remaining dimensions (i.e., goal of teaching and dividing youngsters into ability groups or not) no similarities were found between the traditional, educational sporting and efficiency groups (respectively, $M d n=1$, $M d n=3, M d n=5$ ).

Characteristics of teaching approaches (interviews results)

In the following part, the seven dimensions of TAMA will be explained more in-depth, based on results of the interviews. In doing so, a comparison will be made between the responses of martial arts teachers of the three groups.

\section{Goal of teaching}

Teachers in this study have similar goals when teaching martial arts to youngsters. Imparting respect, discipline, assertiveness, social skills, enjoyment and teaching fighting skills were some of the goals that were considered important by all interviewed teachers.

However, results showed that the main objectives martial arts teachers wish to pursue and the extent to which they emphasised certain goals vary between teachers using different teaching approaches.

The majority of teachers using a traditional approach $(n=6)$ stated that pedagogically-oriented goals and striving towards unity between internal (mental) and external (physical) elements are their main objectives: 
Table 2. Total scores on TAMA of the martial arts teachers.

\begin{tabular}{|c|c|c|c|}
\hline & Subjects* & $\begin{array}{c}\text { Total score TAMA } \\
(\min .=7, \max .=35)\end{array}$ & \\
\hline \multirow[t]{8}{*}{$\begin{array}{l}\text { Group 1: Traditional } \\
\text { (tot. score }=7-16 \text { ) }\end{array}$} & $\mathrm{A} 1$ & 7 & \multirow{8}{*}{ 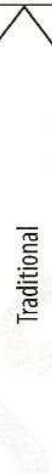 } \\
\hline & A3 & 9 & \\
\hline & A4 & 11 & \\
\hline & $A 2$ & 12 & \\
\hline & $K 2^{*}$ & 12 & \\
\hline & $\mathrm{K} 3^{*}$ & 13 & \\
\hline & A5 & 14 & \\
\hline & $K 7^{*}$ & 16 & \\
\hline \multirow{5}{*}{$\begin{array}{l}\text { Group 2: Educational } \\
\text { sporting } \\
\text { (tot. score }=17-25 \text { ) }\end{array}$} & $K 5^{*}$ & 18 & \multirow{5}{*}{ 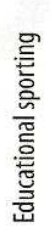 } \\
\hline & $\mathrm{K} 10^{* *}$ & 20 & \\
\hline & $K 6^{* *}$ & 21 & \\
\hline & $K 9^{* *}$ & 22 & \\
\hline & KTB 3 & 24 & \\
\hline \multirow{7}{*}{$\begin{array}{l}\text { Group 3: Efficiency } \\
\text { (tot. score }=26-35 \text { ) }\end{array}$} & $K 4^{*}$ & 26 & \multirow{7}{*}{ 鸪 } \\
\hline & $\mathrm{K} 1^{*}$ & 27 & \\
\hline & KTB 2 & 29 & \\
\hline & $K 8^{* *}$ & 30 & \\
\hline & KTB 4 & 31 & \\
\hline & KTB 1 & 34 & \\
\hline & KTB 5 & 35 & \\
\hline
\end{tabular}

${ }^{*} \mathrm{~A}=$ aikido, $\mathrm{K}=$ karate, $\mathrm{KTB}=$ kick-/Thaiboxing; ${ }^{* *}$ Shotokan karate; ${ }^{* * *}$ Kyokushinkai karate.

For all these dimensions two characteristics were described, one typical for a traditional and one for an efficiency approach. Scores on TAMA could vary from 1 to 5 ( 1 = typical traditional, $5=$ typical efficiency). If an item was scored in between, it was considered as a characteristic for an educational sporting approach.

The data collected with TAMA were discussed with the second author. This resulted in a modification of certain of its dimensions. Four items (i.e., kata, competition, dress code, addressing the teacher) were deleted, because they were not applicable for all martial arts styles. One specific item was changed for greater objectivity. Instead of asking how much attention was paid to the opening and closing ritual, the duration of this ritual was taken into consideration. Based on the vid$\mathrm{eo}$, this item was rated by measuring the ritual duration. The final framework contains 7 items (Table 1).

The score on each TAMA item was verified with what had been heard and seen during the pre-interactive interview and the interactive observation. Furthermore, to check the reliability of the scores in the definitive TAMA framework, two independent researchers, who are both experienced in martial arts research, were asked to rate TAMA for a random selected number of martial arts teachers, based on the transcripts of the interview and the videos of the training sessions. Through the use of Cohen's Kappa (K) the inter-rater reliability was determined. Values of $\mathrm{K}$ from 0.6 to 0.7 were found, which are considered to be good results [49].

After the data collection, all interviews were transcribed verhatim. Afterwards the information was organised and processed through the use of the NVIVO qualitative data analysis software programme.

\section{Results}

\section{Analysis of the scores on TAMA}

A total score on TAMA was calculated for each interviewed martial arts teacher. Based on these scores, subjects were divided into three groups (i.e., traditional, educational sporting and efficient martial arts teachers) (Table 2). This revealed that all aikido teachers were 
Table 1. Teaching Approach in Martial Arts framework (TAMA).

\begin{tabular}{|c|c|c|c|c|c|c|c|}
\hline \multirow{2}{*}{ Dimensions } & \multicolumn{7}{|c|}{ Teaching approach } \\
\hline & Traditional & & & & & & Efficient \\
\hline 1. Goal of teaching & $\begin{array}{l}\text { Striving for unity between } \\
\text { internal (spiritual and } \\
\text { mental) and external } \\
\text { (physical) elements + } \\
\text { pedagogical oriented aims }\end{array}$ & 1 & 2 & 3 & 4 & 5 & $\begin{array}{l}\text { Sporting activity with the focus on } \\
\text { physical aspects }\end{array}$ \\
\hline $\begin{array}{l}\text { 2. Duration opening } \\
\text { and closing ritual* }\end{array}$ & Longer than one minute & 1 & 2 & 3 & 4 & 5 & There is no ritual \\
\hline 3. Ability groups & $\begin{array}{l}\text { Martial artists are not } \\
\text { divided into ability groups }\end{array}$ & 1 & 2 & 3 & 4 & 5 & $\begin{array}{l}\text { Martial artists are divided into } \\
\text { ability groups }\end{array}$ \\
\hline 4. Teaching techniques & $\begin{array}{l}\text { Teaching techniques in } \\
\text { different parts (analytical) }\end{array}$ & 1 & 2 & 3 & 4 & 5 & $\begin{array}{l}\text { Teaching techniques in their whole } \\
\text { (global) }\end{array}$ \\
\hline 5. Sparring & $\begin{array}{l}\text { Only one person attacks + } \\
\text { they have to help each other }\end{array}$ & 1 & 2 & 3 & 4 & 5 & $\begin{array}{l}\text { Both persons attack and want to } \\
\text { win }\end{array}$ \\
\hline $\begin{array}{l}\text { 6. Use of traditional or } \\
\text { efficient techniques }\end{array}$ & $\begin{array}{l}\text { Hold on to traditional } \\
\text { techniques }\end{array}$ & 1 & 2 & 3 & 4 & 5 & $\begin{array}{l}\text { Tolerate adjustments if a technique } \\
\text { can be more efficient }\end{array}$ \\
\hline $\begin{array}{l}\text { 7. Response to } \\
\text { inappropriate } \\
\text { behaviour }\end{array}$ & $\begin{array}{l}\text { Intrinsically and mentally } \\
\text { oriented punishments (e.g., } \\
\text { motivate verbally...) }\end{array}$ & 1 & 2 & 3 & 4 & 5 & $\begin{array}{l}\text { Extrinsically and physically oriented } \\
\text { punishments } \\
-4=\text { Physical punishments (push } \\
\text { ups, ...) } \\
-5=\text { Suspend someone }\end{array}$ \\
\hline
\end{tabular}

* Quantified: 1 ->60 sec; 2 - 31-60 sec; 3 - 16-30 sec; 4 - 1-15 sec, 5 - no ritual.

the knowledge gained from the expert witnesses, a semistructured interview guide was developed to standardise all interviews. Next to identification questions (e.g., age, years of martial arts and teaching experience, gender), the interview guide included questions regarding the goal of teaching, didactical approach (methods of teaching techniques and ways of grouping youngsters), traditional aspects of martial arts (greeting ceremony, principles of respect and discipline) and problems that were encountered during training. All interviews were conducted by the first author, who is trained in interviewing techniques. A pilot testing of the interview guide preceded the interviews. The pre-interactive indepth interview was organised with all of the 20 subjects. All interviews, ranging from 60 to 90 minutes in length, were taped.

\section{Informal interactive observation}

The first author observed and videotaped one session of a martial arts practice of each subject. During this informal interactive observation, the researcher selected certain moments that seem to characterise the teaching process. These moments, confirmed on the videotape, provided a better insight regarding the internal organisation and teaching approach of the martial arts teachers. At the end of the videotaped training session, the teachers as well as the participants were asked whether the training was different from usual. Scores could vary from 1 (totally different from usual) to 5 (exactly the same as usual). Based on the mean score of the pupils and teachers $(M=4.59)$ it can be assumed that the videotaped training session did not differ from a regular one.

\section{Post-interactive interview and questionnaire}

Within two days after this observation, a post-interactive session was organised with the subjects. It was held to discuss the observed martial arts practice with the subject. During this session, which lasted 45 to 75 minutes, the videotaped martial arts practice was analysed with the teacher in order to give him or her the opportunity to identify and comment those moments of training that were typical for his/her teaching. After this, the subject was asked to complete a questionnaire designed to identify his/her teaching approach, namely the 'Teaching Approach in Martial Arts' framework (TAMA). Based on the interviews of the six expert witnesses above-mentioned and on the semi-structured interview guide developed for the pre-interactive interviews, this framework was developed. Its goal was to collect empirically based data to identify different teaching approaches demonstrated by the martial arts teachers in order to classify them into different relevant groups. In total, 11 dimensions were included: (a) goal of teaching, (b) opening and closing ritual, (c) ability groups, (d) teaching techniques, (e) use of traditional or efficient techniques, (f) sparring, (g) response to inappropriate behaviour, (h) kata (i.e., form exercises), (i) competition, (j) dress code, (k) addressing the teacher. 
It is worth mentioning, however, that it is more difficult to find a definition for a modern teaching approach. Donohue and Taylor [42] indicated that a modern training is seen to put more emphasis on the sporting and competitive elements, and limiting the teaching to the physical aspects only. In line with this, Förster [38] did not use the term modern, but described what is opposed to traditional training methods. The author argued that if a practised martial art is interpreted as a martial 'sport', in which notions such as competition, winning and fighting are overvalued, it is in contrast with a traditional teaching approach. According to Trulson [44], teachers are using a modern approach when only free fighting and self-defence techniques were taught.

Theeboom et al. [30] extended the classification of traditional versus modern and categorised martial arts into three approaches. Next to the traditional or holistic approach, the modern approach was divided into a sporting and an efficiency approach. Within the efficiency teaching method the emphasis is on combative aspects and on the efficiency and optimal application of the fighting techniques. The sporting approach does not primarily focus on the acquisition of fighting competence, but rather regards martial arts as a sport with positive effects on the physical, mental and social condition of participants and with technical restrictions in accordance with specific competition rules.

In conclusion, several authors made an attempt to define different approaches used to teach martial arts. These classifications, however, were not based on empirical evidence, but were only descriptive of nature. Consequently, in order to make these concepts operational and to gain a better understanding of the type of guidance of different martial arts teachers, the present study is set up.

The purpose of this study is to make an analysis of different teaching approaches used by martial arts teachers and to develop a framework that identifies these teaching methods. As many different styles and disciplines currently exist, even within one martial art, in this study two research questions are formulated: (a) Do teachers of different martial arts use different teaching approaches? (b) Could different teaching approaches be distinguished within one martial art?

\section{Material and methods}

\section{Participants}

In the present study an analysis was made of different teaching approaches of martial arts teachers. Twenty Flemish $^{2}$ teachers of three different martial arts (i.e., aikido [ $\mathrm{n}=5$ ], kick-/Thai boxing $[\mathrm{n}=5]$, and karate $[n=10])$ were interviewed and observed. All teachers agreed to take part in the study and were teaching a martial art in different martial arts clubs. The teachers had a mean age of $47.50 \pm 9.31$ years, they had already many years of experience in practising a martial art $(M=27.45 \pm 10.65$ years $)$ and in teaching a martial art $(M=18.80 \pm 11.29$ years $)$. In total, 16 men and 4 women (teaching aikido, $n=1$; karate $n=2$; or kick-/Thai boxing, $n=1$ ) participated in the present study.

All interviewees were not randomly selected but were chosen based on the advice of some expert witnesses and had to fulfil several selection criteria. These included that (a) they had to be active in a sports club where young martial artists practise a martial art in a separate group, (b) they had to be teaching martial arts to youth and (c) they had to have at least 2 years of experience as a youth martial arts teacher.

Aikido and kick-Thai boxing were selected according to differences in terms of the amount of physical contact. The former is considered as a soft martial art in which the strength and the intention of an attacker are used against the opponent to neutralise him/her while kick-/Thai boxing is regarded as a hard martial art, where the emphasis is more on parrying (or just directly blocking) an attack and where significantly more power is delivered $[47,48]$. Karate teachers were included because different styles exist within this sports activity (e.g., noncontact styles, such as shotokan karate or full-contact styles, such as kyokushinkai karate). Because of this it is assumed that a wide variety of teaching approaches can be observed within karate.

\section{Data collecting and analysis}

In order to provide an answer to the research questions described above, for each subject, data were collected in three steps, namely (a) a pre-interactive interview, (b) informal interactive observation, (c) post-interactive interview.

\section{Pre-interactive interview}

During the preparatory phase, the interviewer had informal interviews with six expert witnesses. They were involved as a teacher within the governmental coach education programme for martial arts or were active in the aikido, karate or kick-/Thai boxing sports federations. The information contained in these conversations served as background knowledge and was intended to identify different characteristics of teaching approaches used in martial arts. Based on a literature study and 
TAMA - Teaching Approach in Martial arts framework. This instrument is developed in the present study to identify different teaching approaches in martial arts.

Youth - in this article youngsters are considered as 6 to 18 year olds.

\section{Teaching approach $-\mathrm{a}$} way of teaching; in the present study three different approaches were identified (i.e., traditional, educational sporting and efficiency approach).

Traditional approach martial arts teachers using a traditional approach emphasise traditional aspects and pedagogically oriented aims.

Educational sporting approach - In a sporting approach traditional aspects are still important, but martial arts are considered rather more as a sport.

Efficiency approach Martial arts teachers using an efficiency approach focus primarily on competition and the development of performing skills. study in Flanders (Belgium) also reported that for the number of sports clubs by sports activity, martial arts are on the second place [6].

The interest in martial arts may result from the presumption that martial arts involvement can provide positive learning opportunities for youth. For example, in recent years martial arts have increasingly been used as an educational tool in working with young people [7-10]. Furthermore, it is assumed that the practice of martial arts can provide a potential value in physical education classes at school $[11,12]$. In many European countries martial arts are introduced during physical education in secondary schools [13-18]. In Japan it will even become a compulsory program at junior-high schools from 2012 onwards [19].

However, as indicated in sports participation research in general [20-24] and martial arts research in particular [25-27], in order to create educational opportunities through sports a number of contextual factors have to he considered (e.g., characteristics of participants, type of guidance, structural qualities of the sports activity, social context, organisational context). As indicated by these authors, one of the factors that should be taken into account when examining outcomes of sports participation (and especially of martial arts involvement) is the type of guidance that is used.

\section{The terminology of 'teaching' in martial arts research}

Type of guidance is a broad and general term which can refer to many aspects of providing a sports activity, such as teaching, coaching, leadership behaviour, instructing, etc. If the type of guidance is described in martial arts research, reference has mostly been made to 'teaching' in martial arts [c.g., 28-31]. However today, a lack of research exists regarding the terminology of 'teaching' in martial arts. As a consequence it is difficult to determine whether martial arts teachers "teach", "train" or "entertain".

The term 'teaching' is often used in an education context, such as in physical education in schools [32-34]. As Figueroa [35] or Metzler [36], many authors consider that physical education must contribute to and be an integral part of the development of the whole person, such as physical, intellectual, spiritual, individual, cultural and social aspects. As indicated by Brown and Johnson [11] and Murray [37], the approach used in physical education seems to have many similarities with the one used by Asian martial arts teachers. Most Asian martial arts teachers (e.g., judo, aikido, taekwondo) say to seek to develop a unity between body and mind through a specific pedagogy, which includes a mixture of solo practice, rigorous etiquette and performing basic techniques with full mental concentration, no matter how often they are repeated [38]. Consequently, providing an Asian martial art can be situated in a broader educational context, which may explain why the term 'teaching' has mostly been used in martial arts research compared to 'coaching' that is more sport oriented, even if educational goals of sport are well established [39].

\section{Teaching approaches in martial arts}

It is believed that martial arts practice can provide educational opportunities for youth. Therefore, it is however important to consider, among other things, the teaching approach of the martial arts teacher as a critical success factor $[25,26]$.

In research regarding martial arts, some authors pointed out the distinct influence of the martial arts teacher. For example, Cox [40] argued that a great variety in the quality of instructions exist, which could influence the outcome of martial arts practice. Jones et al. [41] reported that the style of the instructor is of major importance to enhance a student's motivation to participate. They indicated that the instructor has inherent personality traits and behaviours and will make choices, which will have an influence on the teaching methods used, which in turn can alter the decisions of the practitioners (behaviours and attitudes). As a result, they concluded that the instructorship is perhaps more important than the martial art that is practised. Additionally, it is worth mentioning that in a study of Theeboom and Vertonghen [31] in which different martial arts teachers were interviewed, one interviewee said: 'There are no good or bad martial arts, there are only good or bad teachers' (p. 45).

To date, a number of authors described different teaching approaches used in martial arts. Mostly a distinction was made between traditional and modern training methods [42-44]. In the study of Nosanchuk and MacNeil [43] and Trulson [44], a martial art was classified as traditional when certain elements such as form exercises (also called 'kata'), a period of meditation and a brief explanation concerning philosophy were present during a training session. According to Back and Kim [45], a martial art should meet four criteria in order to receive the status of a traditional approach: (a) recognition of the cultural origin, (b) reference to fighting, (c) presence of artistic aspects through formal training (i.e., forms or drills), and (d) working toward spiritual development. Theeboom and Van Stiphout [46] also described the traditional approach as 'holistic' and added that within this approach participants strive for unity and coordination between internal (e.g., spiritual and mental) and external (e.g., physical) elements.

The term "kata" refers to detailed choreographed patterns of movements practised either solo or in pairs. 